\title{
Reticuloendothelial System and Neoplasma*
}

\author{
By \\ Yukio Ishibashi \\ From the Department of Surgery, Institute for Infectious Diseases, \\ University of Tokyo, Tokyo: Director: Prof. Y. I shibashi
}

(Received for publication, November 25, 1963)

\begin{abstract}
We investigated immune responses of tumor-bearing host to understand some possible relationships between reticuloendothelial system and neoplasma.

The lower levels of antibody production to heterologous antigens were observed in tumor-bearing animals, as compared with tumor free controls. In cancer patients, however, we failed to find depressions of humoral immune responses even in the later stages. On the other hand, delayed type of hypersensitivity, as determined by tuberculin reaction and skin homograft reaction, is significantly weaker in both cancer-bearing animals and patients. This suggests that such a qualitative deficiency of immune responses is responsible for the development and progression of neoplasm. It might, therefore, be supposed that host can counteract neoplastic disease by correcting this deficiency. That bone marrow transplantation from closely related donors might help in this approach is suggested.
\end{abstract}

The studies discussed in this paper are concerned with the possible immunopathological relationship between reticuloendothelial system (RES) and neoplasma.

In regard to nonspecific host factors, Pillemer's properdin, that had been considered as one of the factors of natural host resistance, was determined in the sera of cancer patients by both bacteriophage neutralization and zymosan assay methods. The distribution and range of the units of fifty per cent phage neutralization $\left(\mathrm{PhN}_{50}\right)$ and those of zymosan assay in cancer patients are almost the same as in normal subjects in Figs. 1 and 2. No absolute correlation could be found between the serum properdin levels and the clinical conditions of cancer patients.

Capacities of humoral immune response in tumor-bearing mice and cancer patients were studied by assaying the serum antibody after active immunization with tetanus toxoid. Although the primary response to produce anti-tetanus toxin antibody generally falls in mice, the secondary response developed at the same

石橋幸婎

* This paper was delivered at the 3rd General Meeting of the Japan Society of the Reticuloendothelial System, May 31, 1963 in Nagoya. 


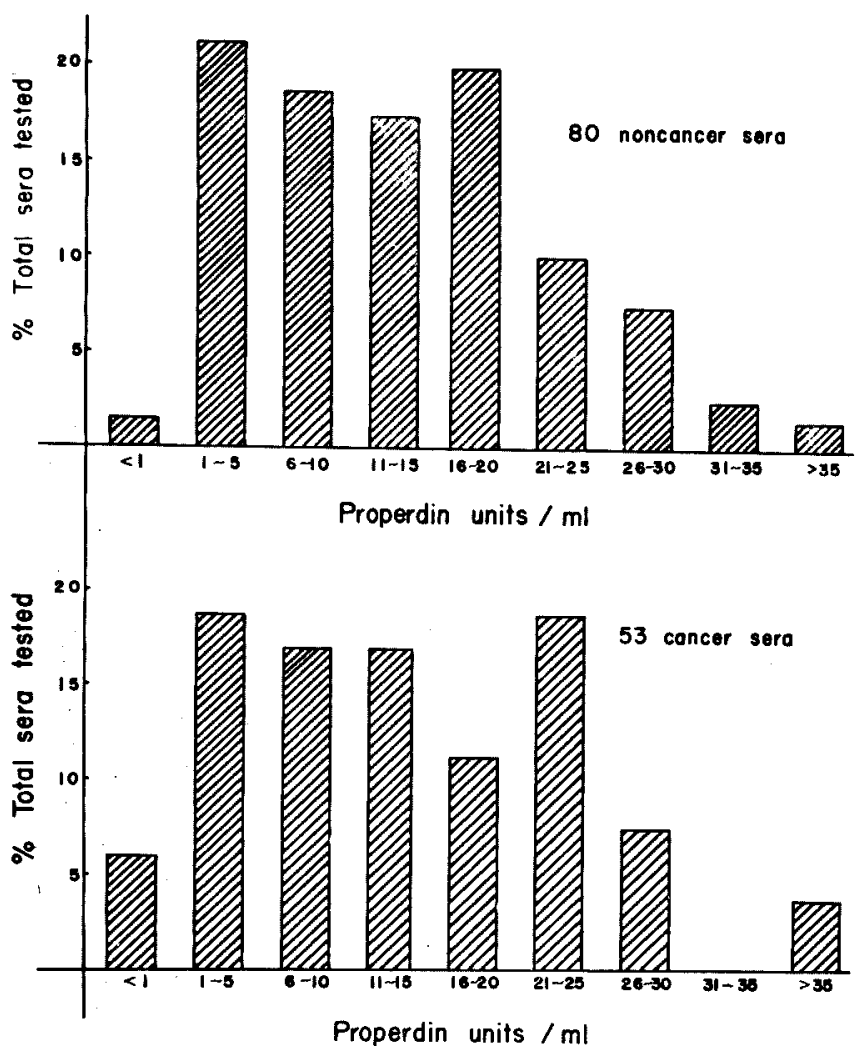

Fig. 1. Phage assay.

level in tumor-bearing and normal mice when antibody was determined on the 6th day after booster injection of tetanus toxoid. The level of antibody in tumor-bearing mice, however, decreased abruptly on the 12th day, whereas that in normal mice remained unchanged and increased afterward. On the other hand, the primary response to tetanus toxoid developed in human, but the level of this response in cancer patients was inferior to that in normal subjects. In the secondary response, however, the cancer group produced an equal or more amounts of antitoxin antibody as normal group. These observations suggest that the cancer patients maintain the capacity of humoral antibody production fairly well even in the late stage, including serum properdin level.

Next, the other type of immune response, i.e. delayed type of hypersensitivity reaction in tumor-bearing animals was studied. The skin homografts from $\mathrm{C} 57$ B1 mice persisted much longer in $\mathrm{d} d \mathrm{D}$ mice with Ehrlich carcinoma than in the ddD mice without carcinoma. The average survival times of skin homografts were 21.4 days and 9.4 days respectively. The homograft reaction against the second set grafts in tumor-bearing mice is also weaker as compared with tumor-free 


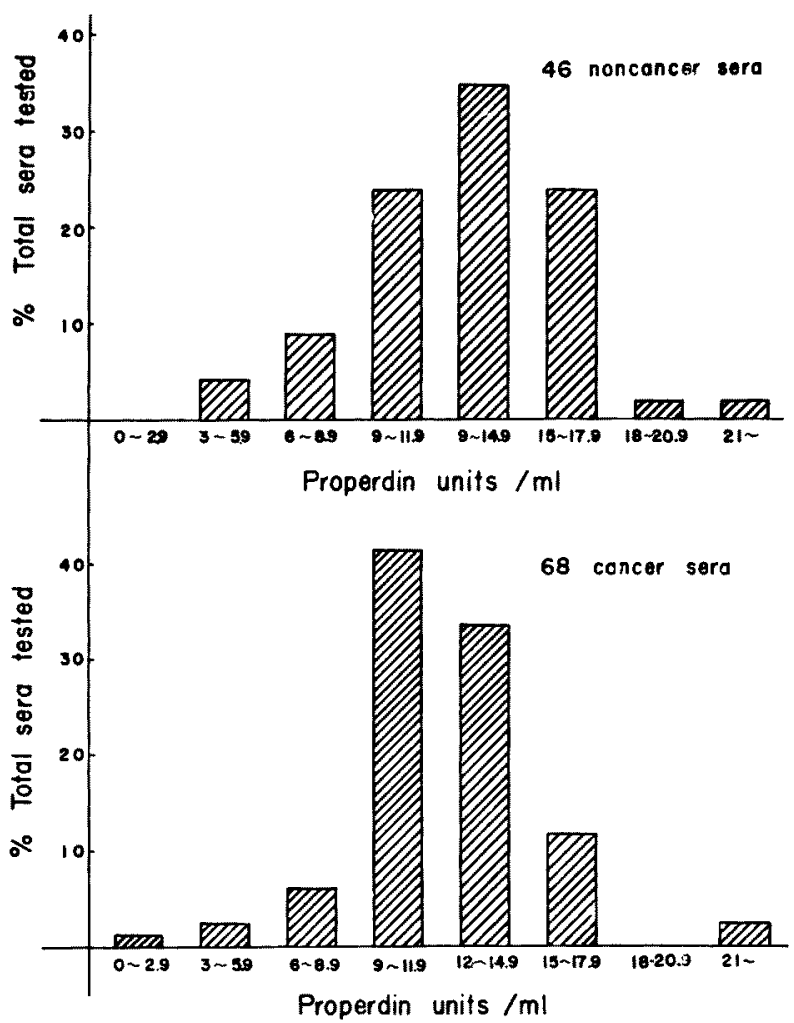

Fig. 2. Zymosan assay.

controls. In human, skin homografts performed in cancer patients persisted much longer than in controls of patients without cancer. The average survival times of the homografts were 36.5 days and 19 days respectively. A test of tuberculin hypersensitivity, one of the typical delayed type hypersensitivity, was performed on 124 cancer patients, 72 non-cancer patients and 146 healthy but 50 years or more old persons. Of the cancer patients tested, only 29.8 per cent showed a positive skin reaction. This is a remarkably low percentage of positive

Table I. Tuberculin Test

\begin{tabular}{c|r|r|r|r|r|r}
\hline \multirow{2}{*}{ Patients } & \multicolumn{2}{|c|}{ Cancer } & \multicolumn{2}{|c|}{ Non-cancer } & \multicolumn{2}{c}{ Healthy persons } \\
\cline { 5 - 8 } Reaction & Cases & Per cent & Cases & Per cent & Cases & Per cent \\
\hline+ & 37 & 29.8 & 60 & 83.3 & 102 & 69.9 \\
\pm & 9 & 7.3 & 2 & 2.8 & 12 & 8.2 \\
$\cdots$ & 78 & 62.9 & 10 & 13.9 & 32 & 21.9 \\
\hline Total & 124 & 100.0 & 72 & 100.0 & 146 & 100.0
\end{tabular}


reactions if it is compared with those of the non-cancer patients and healthy old persons, i.e. 83.3 and 69.9 per cent respectively. The rate of conversion of the tuberculin reaction following injection of BCG is approximately 10 per cent in cancer patients as opposed to 95 to 99 per cent in the general populations. From these observations, as shown in Table I, one can assume that the delayed type hypersensitivity reaction is deficient in cancer. In view of the long known rôle of RES cell in immune response, it seems logical to consider that this deficiency of the delayed hypersensitivity reaction is one of the qualitative disturbances of RES function in the presence of cancer. It might, therefore, be possible to counteract neoplastic diseases by correcting this immunological deficiency in cancer patients.

In the hope of increasing the host resistance of patients to control cancer, several series of preliminary experiments with tumor autoimmunity were undertaken in laboratory animals with the results to support the clinical attempt of the tumor auto-transplantation. The data are summarized as follows:

Subcutaneous injection of Yoshida ascites tumor in rats and Ehrlich ascites tumor in the $\mathrm{ddD}$ and $\mathrm{C57 \textrm {B } 1}$ mice inhibitied significantly the growth of these tumors inoculated intraperitoneally later in each animal. Rats with both intraperitoneal and subcutaneous Yoshida ascites tumor are much more sensitive to anticancer agents than those with intraperitoneal Yoshida ascites tumor alone.

These results suggest that the inoculation of the tumor cells at a site remote from that of origin makes it possible for the host to respond immunologically to an antigenic difference to the tumor cells transplanted heterotopically and such immunological phenomena may be also involved in the mechanisms of action of the anticancer agents to neoplasma.

In clinical experiences, usually two, sometimes four autologous tumor grafts, $2 \mathrm{~cm}$ wide and $0.5 \mathrm{~cm}$ thick, prepared from patients' own cancer tissue, were transplanted intradermally in the abdominal wall or upper thigh. Many patients who received such grafts were treated with a small dose of anticancer agents. Although most tumor grafts developed to small palpable nodules within one month, further behaviors of them were quite variable, i.e. some grafts grew slowly after a along period of dormancy, others grew rapidly within a few months. It was interesting that the second tumor graft prepared from the first one grew more slowly than the first and the third graft from the second one grew still much more slowly. From these findings one might postulate that cancer patients have an anticancer resistance in some manner, which may be stimulated by autologous heterotopical tumor graft. A series of 117 cancer patients who received tissue grafts is listed in Table II. The one-year survival rate was 18.8 per cent. The 2-year survival rate was 3.4 per cent. It seems clear that although the autotransplantation of tumor tissue benefits some patients, its effect is not sufficiently great in general, especially little or none for the patients with widely disseminated disease. 
TABLE II. Survival Rate at 1 Month to 24 Months after Treatment

\begin{tabular}{|c|c|c|c|c|c|c|c|c|}
\hline $\begin{array}{l}\text { Time of } \\
\text { survival }\end{array}$ & $\begin{array}{l}\text { Gastric } \\
\text { cancer }\end{array}$ & $\begin{array}{c}\text { Pancreas } \\
\text { cancer }\end{array}$ & $\left|\begin{array}{c}\text { Rectum \& } \\
\text { colon-ca }\end{array}\right|$ & $\begin{array}{l}\text { Lung } \\
\text { cancer }\end{array}$ & $\begin{array}{l}\text { Breast } \\
\text { cancer }\end{array}$ & $\begin{array}{l}\text { Miscell. } \\
\text { cancer }\end{array}$ & Total & $\begin{array}{l}\text { Per cent } \\
\text { alive }\end{array}$ \\
\hline 1 month & $\begin{array}{r}56 / 62 \\
(90.3)\end{array}$ & $\begin{array}{l}6 / 8 \\
(75.0)\end{array}$ & $\begin{array}{l}8 / 9 \\
(88.8)\end{array}$ & $\begin{array}{c}9 / 12 \\
(75.0)\end{array}$ & $\begin{array}{l}6 / 7 \\
(85.7)\end{array}$ & $\begin{array}{c}16 / 19 \\
(84.1)\end{array}$ & $\begin{array}{l}101 / \\
117\end{array}$ & 86.3 \\
\hline 3 months & $\begin{array}{r}38 / 62 \\
(61.3)\end{array}$ & $\begin{array}{l}4 / 8 \\
(50.0)\end{array}$ & $\begin{array}{l}6 / 9 \\
(66.6)\end{array}$ & $\begin{array}{c}7 / 12 \\
(58.3)\end{array}$ & $\begin{array}{l}5 / 7 \\
(71.4)\end{array}$ & $\begin{array}{c}12 / 19 \\
(63.1)\end{array}$ & $\begin{array}{l}72 / \\
117\end{array}$ & 61.5 \\
\hline 6 months & $\begin{array}{l}20 / 62 \\
(23.3)\end{array}$ & $\begin{array}{l}2 / 8 \\
(25.0)\end{array}$ & $\begin{array}{l}4 / 9 \\
(44.4)\end{array}$ & $\begin{array}{c}4 / 12 \\
(33.3)\end{array}$ & $\begin{array}{l}4 / 7 \\
(57.1)\end{array}$ & $\begin{array}{c}7 / 19 \\
(36.8)\end{array}$ & $41 /$ & 35.0 \\
\hline 12 months & $\begin{array}{l}10 / 62 \\
(16.1)\end{array}$ & $\begin{array}{l}1 / 8 \\
(12.5)\end{array}$ & $\begin{array}{l}3 / 9 \\
(33.3)\end{array}$ & $\begin{array}{c}1 / 12 \\
(8.3)\end{array}$ & $\begin{array}{l}3 / 7 \\
(42.8)\end{array}$ & $\begin{array}{c}4 / 19 \\
(22.2)\end{array}$ & $22 /$ & 18,8 \\
\hline 24 months & & & $\begin{array}{l}2 / 9 \\
(22.2)\end{array}$ & $\begin{array}{c}1 / 12 \\
(8.3) \\
\end{array}$ & & $\begin{array}{c}1 / 19 \\
(5.2)\end{array}$ & $4 /$ & 3.4 \\
\hline total & 62 & 8 & 9 & 12 & 7 & 19 & 117 & \\
\hline
\end{tabular}

In the present series of patients given tissue grafts, there is little evidence that tissue immune response has been developed. This may be explained that the ineffectiveness of auto-transplantation is directly correlated with the deficiency of the autoimmune mechanism in cancer patients. As mentioned previously in this paper, such sort of immunological deficiency in cancer patients was suggested by the decreased incidence of positive tuberculin test and the lowered skin homograft reaction in cancer patients. On these bases, we believe that the immunological defence mechanism of cancer patients should be studied more closely and means of restoring the capacity of immune response of delayed type should be sought in order to obtain the more desired effect with activity immunization such as cancer auto-transplantation.

The effect of homologous or isologous bone marrow transplantation to prolong the survival time of tumor-bearing animals was presented by us. The possible rôle of the transplanted bone marrow cells may be to restore the impaired immunological capacity in tumor-bearing animals. In order to elucidate the mechanism of the action of bone marrow cells, we are now in attempts if the delayed sensitivity could be transferred to tumor-bearing animals by the repeated injection of bone marrow cells from closely related donors. 


\section{References}

1) Pillemer, L., Science, 1954, 120, 279.

2) Barlow, J.L., J. Immunol, 1958, 80, 349.

3) Stern, K., The international soceity for research on the reticuloendothelial system, third international symposium, 1958, pp. 233.

4) Halpern, B.N., ibid., pp. 259.

5) Old, L.J., Ann. N.Y. Acad. Sci., 1960, 88, 264.

6) Witebsky, E., Cancer Res., 1956, 16, 831.

7) Graham, J.B., Surg. Gynec. Obstet., 1959, 109, 131.

8) Finney, J.W., Cancer Res., 1960, 20, 351.

9) Ishibashi, Y., Gekachiryo (Jap.), 1962, 6, 1.

10) Ishibashi, Y., Tohoku J. exp. Med., 1961, 31, 319.

11) Furth, J., Cancer Res., 1963, 23, 21.

12) Sekiguchi, M., Gann, 1962, 53, 129.

13) Sekiguchi, M., Gann, 1962, 53, 309. 